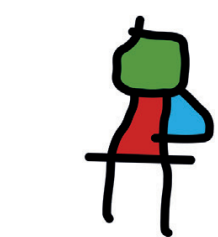

SEICAIP

\section{Allergologia et \\ immunopathologia}

Sociedad Española de Inmunología Clínica,

Alergología y Asma Pediátrica

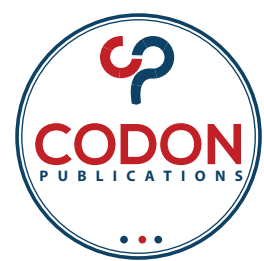

ORIGINAL ARTICLE

OPEN ACCESS ㄷ)(1)(2)

\title{
Validation of the food allergy independent measure and the EuroPrevall food allergy quality of life questionnaire for children 8-12 years translated into Spanish
}

\author{
Dah-Tay Jang, María Pérez Sabido, Elisa Buendía, Laura Ibáñez, María Nieto, \\ Ester Bartoll, Blanca Selva, Sonia Uixera, Antonio Nieto, Ángel Mazón*
}

Unit of Pediatric Allergy and Neumology, Children's Hospital La Fe, Valencia, Spain

Received 15 June 2021; Accepted 9 November 2021

Available online 1 January 2022

\section{KEYWORDS \\ Children; \\ Food Allergy; \\ Quality of Life; \\ Spanish; \\ Validation}

\begin{abstract}
Background: Different questionnaires have been developed to measure quality of life (QoL) in patients with food allergy. Our aim was to validate a Spanish translation of the Food Allergy Independent Measure (FAIM) and the EuroPrevall Food Allergy Quality of Life QuestionnaireChild Form (FAQLQ-CF) for children aged 8-12 years.

Methods: Sixty children with a diagnosis of IgE-mediated allergy to food completed the questionnaires. The internal consistency was evaluated with Cronbach's alpha. The correlation of FAQLQ-CF with FAIM was assessed to test construct validity. We compared both values with the diagnosis of anaphylaxis to evaluate discriminant validity.

Results: Cronbach's alpha was in the range of $0.654-0.863$ for the four domains of FAQLQ-CF and 0.779 for FAIM. There were no criteria to remove questions from the questionnaires. Significant correlations could be found between FAQLQ-CF and the number of offending foods and the impact on social life (all $r>0.33, P<0.01$ ), and between FAIM and anaphylaxis.

Conclusions: The Spanish translation of FAQLQ-CF showed acceptable internal consistency, good construct validity, and capacity to discriminate patients depending on the number of foods to avoid and the impact on social life. FAIM showed good discriminant capacity for anaphylaxis.

(c) 2022 Codon Publications. Published by Codon Publications.
\end{abstract}

*Corresponding author: Angel Mazon, Unit of Pediatric Allergy and Pneumology, Children's Hospital La Fe, Av. Fernando Abril Martorell 106, Valencia, 46026, Spain. Email address: amazon@comv.es 


\section{Introduction}

Food allergy in children has become an important health problem due to its rising prevalence, severity of reactions, cost of diagnosis and treatment of the disorder, and the impact on quality of life $(\mathrm{QoL})$ of patients and their families. ${ }^{1,2}$

The identification of offending foods, the education on recognition and early treatment of symptoms, and the use of recent procedures such as desensitization or oral tolerance induction can have a beneficial influence on QoL. ${ }^{3}$ To evaluate these, the use of specific tools is needed.

Thus, questionnaires have been designed to measure and monitor QoL in different groups of patients. The EuroPrevall initiative, ${ }^{4,5}$ funded by the Framework Programme FP6 of the European Union, has developed specific questionnaires for parents of children with allergy, adolescents, and children between 8 and 12 years of age..$^{6-9}$ Implementing the use of common questionnaires across different countries requires their translation into local language and validation in different settings. We aimed to validate the Spanish (Spain) translation of Food Allergy Independent Measure (FAIM) and EuroPrevall questionnaire on Food Allergy Quality of Life-Child Form (FAQLQ-CF) for children aged $8-12$ years. ${ }^{6}$

\section{Material and Methods}

The English versions of FAQLQ-CF and FAIM ${ }^{6}$ were initially translated into Spanish by one of the authors, a pediatric allergist, fluent in English, with vast experience and attended continued daily clinical visits of food allergic children. The translated and the original versions were parallelly reviewed, question by question, by other authors, who were also practising pediatric allergists, fluent in English, to reach agreed versions. These were back translated to English by a native speaker who was a professional bilingual translator. The back translated versions were checked with the original ones, and they did not show any relevant differences, so the agreed versions were finally used. The versions were first used in a large group of children (results not included) who did not find difficulty in understanding the questions; after this, the questionnaires were used in the group of study. The selected versions are shown in the online supplement (Supplementary file 1).

Children, aged 8-12 years, with food allergy filled in the questionnaires according to the instructions shown therein. They had been diagnosed with active IgE-mediated food allergy based on compatible symptoms and demonstrated specific IgE by means of skin prick tests and/or serumspecific lgE. The patients completed the questionnaires during a visit scheduled for a food challenge with one of the offending foods, at the start of the challenge before any reactions could occur during the procedure. Patients were invited to participate regardless of the severity of previous reactions or the number of sensitizing foods to not bias the sample.

The FAQLQ-CF included 24 questions, corresponding to four domains: seven questions on allergen avoidance, five on risk of accidental exposure, six on emotional impact, and six on dietary restrictions.
A second part included FAIM, a tool that has demonstrated relevance, reliability, and face validity as independent measures (IMs) of food allergy, which has been used to measure the construct validity of the questionnaire. ${ }^{10}$ It has four questions on expectation of outcome (EO), that is, expectation of what could happen after exposure, and two questions on IM, that is, the perceived number of foods to avoid and the perceived effect on social activities. The diagnosis of anaphylaxis was collected from the electronic records of the patients. Anonymity of responders was warranted, and the study was approved by the Ethics Committee (No. 2020-003-1).

Possible answers to the questions followed a graphic Likert scale, ranging from 0 to 6, with lower values associated to better QoL. Cronbach's alpha was used to test internal consistency of FAQLQ-CF domains and FAIM. Additional measures such as corrected item-total correlations and Cronbach's alpha, if an item were deleted, as well as the Spearman's correlation of the questions in FAQLQ-CF with those in FAIM, were also calculated. The values of FAQLQ-CF and FAIM were compared in children with and without the diagnosis of anaphylaxis by means of the Mann-Whitney $U$ test. The statistical study was performed with the software programme SPSS 15.0, 2006 (Chicago, Ill, USA).

\section{Results}

The questionnaires were completed by 60 children whose characteristics are shown in Table 1. There were no missing answers.

The values of Cronbach's alpha and additional measures for the four domains of FAQLQ-CF are shown in Table 2. The values were above 0.7, except for the domain of "Risk of Accidental Exposure," which was 0.654 (>0.60 is considered acceptable by some authors, although a value of 0.70 is more often recommended). Likewise, none of corrected item-total correlations was under 0.3 , and none of the changes in Cronbach's alpha, if an item were deleted, showed a marked increase. When there is any of these

Table 1 Demographic and clinical characteristics of the study groups.

\begin{tabular}{clclr}
\hline Gender & Male & $40(66.6)$ & $\begin{array}{l}\text { Offending } \\
\text { food }\end{array}$ & $\mathrm{n}$ \\
Age (years) & $\begin{array}{l}\text { Female } \\
\text { Mean } \\
\text { (range) }\end{array}$ & $\begin{array}{c}20(33.3) \\
10.6(8-12.9)\end{array}$ & $\begin{array}{l}\text { Milk } \\
\text { Egg }\end{array}$ & 4 \\
Number of & 1 & & Walnut & 32 \\
offending & 2 & $24(40)$ & Hazelnut & 15 \\
foods & 3 & $14(25)$ & Peanut & 11 \\
& 4 & $7(11.6)$ & Cashew nut & 7 \\
& 5 & $6(10)$ & Pistachio & 5 \\
& 6 & $6(10)$ & Kiwi & 10 \\
& 7 & $1(1.7)$ & Peach & 14 \\
Anaphylaxis & Yes & $2(3.3)$ & Fish & 7 \\
& No & $26(43.3)$ & Crustaceans & 6 \\
& & $34(56.7)$ & Others & 26 \\
\hline
\end{tabular}


Table 2 Values of Cronbach's alpha for the whole Food Allergy Quality of Life Questionnaire-Child Form (FAQLQ-CF), its separate domains, and for the whole Food Allergy Independent Measure (FAIM) and its six separate questions (EO1-EO4, IM1, IM2).

\begin{tabular}{lcccc}
\hline & $\begin{array}{c}\text { No. of } \\
\text { questions }\end{array}$ & $\begin{array}{c}\text { Cronbach's } \\
\text { alpha }\end{array}$ & $\begin{array}{c}\text { Cronbach's alpha if an item } \\
\text { were deleted (range) }\end{array}$ & $\begin{array}{c}\text { Corrected item/total } \\
\text { correlation (range) }\end{array}$ \\
\hline Whole FAQLQ-CF & 24 & 0.929 & $0.923-0.929$ & $0.354-0.759$ \\
Allergen avoidance & 7 & 0.863 & $0.829-0.862$ & $0.489-0.729$ \\
Risk of accidental exposure & 5 & 0.654 & $0.565-0.645$ & $0.310-0.479$ \\
Emotional impact & 6 & 0.812 & $0.766-0.795$ & $0.532-0.641$ \\
Dietary restrictions & 6 & 0.769 & $0.705-0.771$ & $0.379-0.631$ \\
Whole FAIM & 6 & 0.789 & $0.707-0.794$ & $0.402-0.731$ \\
EO1: Chance of accidental exposure & & & 0.774 & 0.465 \\
EO2: Chance of severe reaction & & & 0.638 & 0.638 \\
EO3: Change of dying & & & 0.766 & 0.517 \\
EO4: Chance of not acting effectively & & & 0.707 & 0.731 \\
IM1: Number of foods to avoid & & 0.753 & 0.567 \\
IM2: Effect on social life & & 0.794 & 0.402 \\
\hline FAIM: Food Aller & & & \\
\hline
\end{tabular}

FAIM: Food Allergy Independent Measure; FAQLQ-CF: Food Allergy Quality of Life Questionnaire-Child Form.

two criteria, the removal of a question is generally recommended. The values for each specific question are shown in Supplementary file 2.

The value of Cronbach's alpha for FAIM (with six questions) was 0.779; additional measures for each question are shown in Table 2. According to the above criteria, no removal of questions would be recommended either.

The correlation between the scores of the questionnaire and FAIM, to evaluate construct validity, was significant $(r=0.453, P<0.001)$. There was a positive correlation between the scores of each domain and the global FAIM, mainly due to correlations with the IM, but not much with EO, questions. The correlations of all questions in FAQLQ-CF and FAIM are also shown in Table 3.

The diagnosis of anaphylaxis was associated with a worse value of FAIM $(P=0.03)$, but not with the value of the whole FAQLQ-CF or its domains, as shown in Table 4.

To test the floor and ceiling effect, the number of patients with possible highest and lowest scores for the whole FAQLQ-CF, for each domain, and for FAIM are shown in Table 5. In all cases, the percentage was below 15\%; values under this are considered acceptable.

\section{Discussion}

Validation of questionnaires in different languages and for different populations is essential before they can be recommended for use in clinical settings. ${ }^{10,11}$ This is being carried out in different countries. ${ }^{12-16}$ One of the EuroPrevall questionnaires on QoL in food allergy, for parents of allergic children, has been validated in Spanish by our and another group. ${ }^{17,18}$ In this case, we aimed to validate the questionnaire for children aged 8-12 years.

We received good results, in terms of internal consistency of FAQLQ-CF, with good or at least acceptable results in the four domains. ${ }^{19}$ It is common to find significant correlations between different questions as we did (results not shown). This could lead to consider whether the same information would be obtained if the number of questions is reduced. ${ }^{19,20}$ Nevertheless, suggested criteria for removing somehow redundant questions, as described in results, were not met, so it would be recommended to keep the current questions.

The potential severity of food allergy, as perceived by the patient, is evaluated through the questions in the FAIM. This has also shown a good Cronbach's alpha, which indicates good internal consistency, and no criteria for removal of questions have been found either. It is important to state that the wording of the fourth question must have a negative sense and be highlighted, to avoid misinterpretations, as it happened to us with the questionnaire for parents, in which the wording in a positive sense led to a worse Cronbach's alpha. ${ }^{18}$ The current version in the online supplement should be recommended for use.

One way to evaluate construct validity of the questionnaire, the degree to which it measures what it tries to measure, is to test the correlation between FAQLQ-CF and independent FAIM. ${ }^{6}$ Our results have shown a significant correlation, which would support its validity. Nevertheless, that correlation has been good for the global values of FAQLQ-CF and FAIM (Table 3) mainly due to correlation with IM questions, with less contribution of EO questions. The everyday QoL is more related to IM questions than to EO questions, which in turn are more associated to severe allergy. Children with anaphylaxis had worse FAIM scores than those without reactions (Table 4) in only two questions, in chance of severe reaction (EO2) and in chance of dying (EO3). There was no difference in questions of chance of accidental exposure (EO1) and chance of not acting effectively (EO4), which could be interpreted as good confidence in avoiding the food and treating adequately if needed. On the other hand, there were not significant differences in the whole FAQLQ or its domains according to the diagnosis of anaphylaxis.

The floor and ceiling effects, which evaluate the number of patients with possible maximal and minimal scores, showed a low percentage (Table 5). When this exceeds $15 \%$, the ability of a questionnaire to differentiate and classify patients is impaired. ${ }^{20}$ Therefore, these findings, together 
Table 3 Spearman's correlation coefficient of the Food Allergy Quality of Life Questionnaire-Child Form (FAQLQ-CF) score, domains, and Food Allergy Independent Measure (FAIM) score and its questions.

\begin{tabular}{|c|c|c|c|c|c|c|c|}
\hline \multirow[b]{2}{*}{ FAQLQ-CF } & \multicolumn{7}{|c|}{ FAIM } \\
\hline & Total & E01 & EO2 & EO3 & EO4 & IM1 & IM2 \\
\hline Total & $0.45^{* *}$ & 0.24 & 0.24 & 0.13 & $0.36^{* *}$ & $0.51^{* *}$ & $0.52^{* *}$ \\
\hline Allergen avoidance & $0.38^{* *}$ & 0.14 & 0.13 & 0.09 & $0.33^{* *}$ & $0.46^{* *}$ & $0.47^{* *}$ \\
\hline 4 Read labels & 0.21 & 0.04 & 0.02 & 0.07 & 0.13 & $0.43^{* *}$ & $0.35^{* *}$ \\
\hline 6 Stay for a meal & $0.33^{*}$ & 0.21 & 0.17 & -0.02 & $0.32^{*}$ & $0.39^{* *}$ & $0.34^{* *}$ \\
\hline 7 Try fewer & $0.26^{*}$ & 0.01 & 0.08 & 0.07 & 0.16 & $0.36^{* *}$ & $0.38^{* *}$ \\
\hline 8 Tell beforehand & $0.32^{*}$ & 0.23 & 0.14 & 0.06 & $0.30^{*}$ & 0.25 & $0.41^{* *}$ \\
\hline 9 Check yourself & $0.28^{*}$ & 0.11 & 0.10 & 0.02 & $0.31^{*}$ & $0.31^{*}$ & $0.35^{* *}$ \\
\hline 10 Hesitate eating & $0.34^{* *}$ & 0.18 & 0.20 & 0.10 & $0.36^{* *}$ & $0.35^{* *}$ & 0.22 \\
\hline 15 Explain around & 0.23 & 0.09 & -0.03 & 0.07 & 0.19 & $0.34^{*}$ & $0.36^{* *}$ \\
\hline Risk accidental exposure & $0.43^{* *}$ & $0.25^{*}$ & 0.25 & 0.08 & $0.33^{*}$ & $0.55^{* *}$ & $0.47^{* *}$ \\
\hline 11 Touching foods & $0.27^{*}$ & 0.13 & 0.18 & -0.11 & 0.18 & $0.34^{* *}$ & $0.34^{* *}$ \\
\hline 13 Ingredients change & $0.30^{*}$ & 0.24 & 0.23 & 0.08 & 0.23 & $0.52^{* *}$ & 0.15 \\
\hline 14 Label traces of & $0.28^{*}$ & 0.24 & 0.10 & 0.15 & 0.22 & $0.32^{*}$ & 0.25 \\
\hline 16 People forget & $0.28^{*}$ & 0.16 & $0.32^{*}$ & 0.05 & 0.16 & $0.31^{*}$ & $0.28^{*}$ \\
\hline 17 Others can eat & 0.20 & 0.01 & 0.09 & 0.08 & 0.18 & $0.33^{*}$ & $0.33^{*}$ \\
\hline Emotional impact & $0.49^{* *}$ & $0.27^{*}$ & $0.31^{*}$ & $0.28^{*}$ & $0.34^{* *}$ & $0.45^{* *}$ & $0.45^{* *}$ \\
\hline 19 Allergic reaction? & $0.31^{*}$ & 0.24 & 0.24 & 0.22 & 0.21 & $0.30^{*}$ & 0.23 \\
\hline 20 Eating wrong & $0.38^{* *}$ & 0.22 & $0.29^{*}$ & $0.34^{* *}$ & $0.34^{* *}$ & $0.28^{*}$ & 0.20 \\
\hline 21 Never before & $0.31^{*}$ & 0.22 & 0.19 & 0.21 & 0.12 & 0.24 & $0.29^{*}$ \\
\hline 22 Never get rid & 0.16 & -0.05 & 0.12 & 0.09 & 0.10 & 0.31 & $0.26^{*}$ \\
\hline 23 Not taking account & $0.50^{* *}$ & 0.25 & $0.37^{* *}$ & $0.36^{* *}$ & $0.34^{* *}$ & 0.40 & $0.36^{* *}$ \\
\hline 24 Have food allergy & $0.41^{* *}$ & 0.22 & 0.21 & 0.11 & $0.31^{*}$ & $0.48^{* *}$ & $0.46^{* *}$ \\
\hline Dietary restriction & $0.38^{*}$ & 0.24 & $0.27^{*}$ & 0.05 & $0.33^{*}$ & $0.41^{* *}$ & $0.42^{* *}$ \\
\hline 1 Always watch & $0.35^{* *}$ & 0.25 & $0.32^{*}$ & -0.04 & $0.30^{*}$ & $0.40^{* *}$ & $0.32^{*}$ \\
\hline 2 Eating fewer things & 0.23 & 0.10 & 0.19 & -0.13 & $0.26^{*}$ & $0.42^{* *}$ & $0.28^{*}$ \\
\hline 3 Limited in buying & $0.33^{* *}$ & 0.22 & 0.14 & 0.03 & $0.36^{* *}$ & 0.19 & $0.49^{* *}$ \\
\hline 5 Refuse food & 0.23 & 0.11 & 0.13 & 0.12 & 0.21 & $0.37^{* *}$ & $0.32^{*}$ \\
\hline 12 Don't get treats & 0.12 & 0.09 & 0.22 & 0.11 & 0.07 & 0.22 & 0.03 \\
\hline 18 Don't know taste & $0.25^{*}$ & 0.11 & 0.23 & $0.32^{*}$ & 0.11 & 0.23 & 0.17 \\
\hline
\end{tabular}

Correlation is significant at the ${ }^{*} 0.05 / * * 0.01$ level. EO1: Chance of accidental exposure; EO2: Chance of severe reaction when accidentally exposed; EO3: Chance of dying when accidentally exposed; EO4: Chance of not acting effectively when accidentally exposed; IM1: Number of foods one needs to avoid; IM2: Effect of food allergy on social life.

with the significant correlation with IM questions, point out at good discriminant validity.

There were some limitations in our study. We did not compare the studied questionnaire with generic healthrelated QoL questionnaires. This approach is adequate for comparison between different diseases, ${ }^{11,21}$ but agreement between generic and disease-specific questionnaires is low $^{12,21}$, and disease-specific questionnaires are more suitable to assess relevant changes in QoL of children with food allergy. ${ }^{11,21}$ We did not assess test-retest reliability. For this, a stable unchanged condition is needed. In our study, the questionnaires were filled in at our clinics when children attended for a challenge test, and the results of this could have a striking positive or negative effect on their perception of QoL, and this effect would change the child's condition and the retest results. Evaluation of this reliability is generally assessed through telephone interviews or mailed questionnaires on occasions 1 week to 3 months apart and has shown good to excellent results for questionnaires for food allergic children, adolescents, and adults in English, Japanese, Dutch, and Spanish, ${ }^{8,9,12-14}$ while there are no results for French or Greek. ${ }^{15,16}$

\section{Conclusion}

In summary, this version of the FAQLQ-CF in Spanish has some limitations, but it has shown adequate internal consistency, construct validity, and discriminant capacity through correlations with other aspects of QoL. The translation of the FAIM also had good internal consistency and discriminant capacity for children with anaphylaxis. Thus, they can be used as validated tools for the evaluation of QoL in children with food allergy, at diagnosis and during follow-up periods, and to assess the effectiveness of diagnostic and therapeutic procedures. 
Table 4 Values of the whole Food Allergy Quality of Life Questionnaire-Child Form (FAQLQ-CF), its domains, and the Food Allergy Independent Measure (FAIM) and its questions according to diagnosis of anaphylaxis.

\begin{tabular}{|c|c|c|c|c|}
\hline & \multicolumn{2}{|c|}{ Mean rank } & \multirow[b]{2}{*}{$\mathbf{U}$} & \multirow[b]{2}{*}{$\mathbf{P}$} \\
\hline & $\begin{array}{l}\text { Anaphylaxis (no) } \\
\qquad(\mathrm{n}=36)\end{array}$ & $\begin{array}{l}\text { Anaphylaxis (yes) } \\
\qquad(\mathrm{n}=24)\end{array}$ & & \\
\hline Whole FAQLQ-CF & 30.10 & 30.81 & 431 & 0.88 \\
\hline Allergen avoidance & 29.71 & 31.10 & 421 & 0.76 \\
\hline Risk of accidents & 31.33 & 29.87 & 420 & 0.32 \\
\hline Emotional impact & 30.29 & 30.66 & 436 & 0.92 \\
\hline Dietary restrictions & 31.44 & 29.78 & 417 & 0.71 \\
\hline Whole FAIM & 25.88 & 36.54 & 285 & 0.02 \\
\hline E01: Chance of accidental exposure & 29.28 & 32.10 & 400 & 0.53 \\
\hline EO2: Chance of severe reaction & 24.65 & 38.15 & 243 & 0.002 \\
\hline EO3: Chance of dying & 25.44 & 37.12 & 270 & 0.008 \\
\hline EO4: Chance of not acting effectively & 28.85 & 32.65 & 386 & 0.40 \\
\hline IM1: Number of foods to avoid & 28.87 & 32.63 & 387 & 0.39 \\
\hline IM2: Effect on social life & 28.16 & 33.56 & 363 & 0.23 \\
\hline
\end{tabular}

Table 5 Number (percentage) of patients with possible highest and lowest scores in the whole Food Allergy Quality of Life Questionnaire-Child Form (FAQLQ-CF) the Food Allergy Independent Measure (FAIM) and domains in FAQLQ-CF.

\begin{tabular}{lcc}
\hline & $\begin{array}{c}\text { Lowest } \\
\text { possible score }\end{array}$ & $\begin{array}{c}\text { Highest } \\
\text { possible score }\end{array}$ \\
\hline FAQLQ (whole) & 0 & 0 \\
Allergen avoidance & $1(1.6)$ & 0 \\
Risk of accidental exposure & $2(3.3)$ & 0 \\
Emotional impact & 0 & 0 \\
Dietary restrictions & $1(1.6)$ & 0 \\
Whole FAIM & 0 & $1(1.7)$ \\
\hline
\end{tabular}

\section{Conflict of interest}

The authors declare no potential conflicts of interest with respect to publication of this article.

\section{Funding}

No funding was received for this work.

\section{References}

1. Kansen HM, Le TM, Meijer $Y$, Flokstra-de Blok B, Welsing $P$, van der Ent CK, et al. The impact of oral food challenges for food allergy on quality of life: A systematic review. Pediatr Allergy Immunol. 2018;29(5):527-37. https://doi.org/10.1111/ pai.12905

2. Sicherer SH, Sampson HA. Food allergy: A review and update on epidemiology, pathogenesis, diagnosis, prevention, and management. J Allergy Clin Immunol. 2018;141(1):41-58. https://doi.org/10.1016/j.jaci.2017.11.003

3. Cao S, Borro M, Alonzi S, Sindher S, Nadeau K, Chinthrajah RS. Improvement in health-related quality of life in food-allergic patients: A meta-analysis. J Allergy Clin Immunol Pract. 2021;9(10):3705-14. https://doi.org/10.1016/j.jaip.2021.05.020

4. de Blok BMJ, Vlieg-Boerstra BJ, Oude Elberink JNG, Duiverman EJ, DunnGalvin A, Hourihane JO, et al. A framework for measuring the social impact of food allergy across Europe: A EuroPrevall state of the art paper. Allergy. 2007;62(7):733-7. https://doi.org/10.1111/j.1398-9995.2006.01303.x

5. Mills ENC, Mackie AR, Burney P, Beyer K, Frewer L, Madsen C, et al. The prevalence, cost and basis of food allergy across Europe. Allergy Eur J Allergy Clin Immunol. 2007;62(7):717-22. https://doi.org/10.1111/j.1398-9995.2007.01425.x

6. Flokstra-de Blok BMJ, DunnGalvin A, Vlieg-Boerstra BJ, Oude Elberink JN, Duiverman EJ, Hourihane JO, et al. Development and validation of a self-administered Food Allergy Quality of Life Questionnaire for children. Clin Exp Allergy. 2009;39(1):127-37. https://doi.org/10.1111/j.1365-2222.2008.03120.x

7. Flokstra-de Blok BMJ, van Der Meulen GN, DunnGalvin A, Vlieg-Boerstra BJ, Oude Elberink JNG, Duiverman EJ, et al. Development and validation of the Food Allergy Quality of Life Questionnaire - adult form. Allergy Eur J Allergy Clin Immunol. 2009;64(8):1209-17. https://doi. org/10.1111/j.1398-9995.2009.01968.x

8. Flokstra-de Blok BM, DunnGalvin A, Vlieg-Boerstra BJ, Oude Elberink JN, Duiverman EJ, Hourihane JO, et al. Development and validation of the self-administered Food Allergy Quality of Life Questionnaire for adolescents. J Allergy Clin Immunol. 2008;122(1):139-44, 144.e1-2. https://doi.org/10.1016/j. jaci.2008.05.008

9. van der Velde JL, Flokstra-de Blok BMJ, Vlieg-Boerstra BJ, Oude Elberink JNG, Schouten JP, Dunngalvin A, et al. Test-retest reliability of the Food Allergy Quality of Life Questionnaires (FAQLQ) for children, adolescents and adults. Qual Life Res. 2009;18(2):245-51. https://doi.org/10.1007/ s11136-008-9434-2

10. Muraro A, Dubois AEJ, DunnGalvin A, Hourihane JO, de Jong NW, Meyer R, et al. EAACl food allergy and anaphylaxis guidelines. Food allergy health-related quality of life measures. Allergy Eur J Allergy Clin Immunol. 2014;69(7):84553. https://doi.org/10.1111/all.12405

11. Salvilla SA, Dubois AEJ, Flokstra-de Blok BMJ, Panesar SS, Worth A, Patel S, et al. Disease-specific health-related quality of life instruments for IgE-mediated food allergy. Allergy Eur J Allergy Clin Immunol. 2014;69(7):834-44. https://doi. org/10.1111/all.12427 
12. Mizuno $Y$, Ohya $Y$, Nagao $M$, DunnGalvin A, Fujisawa $T$. Validation and reliability of the Japanese version of the Food Allergy Quality of Life Questionnaire-Parent Form. Allergol Int. 2017;66(2):290-5. https://doi.org/10.1016/j.alit.2016.06.013

13. Antolin-Amerigo D, Cerecedo Carballo I, Muriel A, FernándezRivas M, Diéguez Pastor M, Flokstra-de Blok B, et al. Validation of the Spanish version of the food allergy quality of life questionnaire-adult form (S-FAQLQ-AF). J Investig Allergol Clin Immunol. 2015;25(4):270-5.

14. Knibb RC, Ibrahim NF, Petley R, Cummings AJ, King RM, Roberts $G$, et al. Validation of the Paediatric Food Allergy Quality of Life Questionnaire (PFAQL). Pediatr Allergy Immunol. 2013;24(3):288-92. https://doi.org/10.1111/pai.12060

15. Morou Z, Lyrakos GN, Papadopoulos NG, Douladiris N, Tatsioni A, Dimoliatis IDK. Translation, adaptation and initial validation of Food Allergy Quality of Life Questionnaire: Child form in Greek. Health Psychol Res. 2016;4(1):1-6. https://doi. org/10.4081/hpr.2016.4624

16. Wassenberg J, Cochard MM, DunnGalvin A, Flokstra-de Blok BMJ, Hofer M, Eigenmann PA. Qualité de vie chez l'enfant avec allergie alimentaire validation de la version française des questionnaires spécifiques de qualité de vie. Rev Fr Allergol. 2011;51(4):437-8. https://doi.org/10.1016/j.reval.2011.02.024
17. Manso L, Pineda R, Huertas B, Fernández-Rivas M, Diéguez MC, Cerecedo I, et al. Validation of the Spanish version of the food allergy quality of life questionnaire-parent form (S-FAQLQ-PF). J Investig Allergol Clin Immunol. 2017;27(6):363-9. https://doi. org $/ 10.18176 /$ jiaci.0182

18. Bartoll E, Nieto M, Selva B, Badillo R, Pereira G, Uixera S, et al. Validation of a Spanish version of the EuroPrevall Food Allergy Quality of Life Questionnaire-Parental Form. Allergol Immunopathol (Madr). 2018;46(1):82-6. https://doi. org/10.1016/j.aller.2017.06.004

19. Tavakol M, Dennick R. Making sense of Cronbach's alpha. Int J Med Educ. 2011;2:53-5. https://doi.org/10.5116/ijme.4dfb.8dfd

20. Terwee CB, Bot SDM, de Boer MR, van der Windt DAWM, Knol DL, Dekker J, et al. Quality criteria were proposed for measurement properties of health status questionnaires. J Clin Epidemiol. 2007;60(1):34-42. https://doi.org/10.1016/j. jclinepi.2006.03.012

21. Flokstra-de Blok BMJ, Dubois AEJ, Vlieg-Boerstra BJ, Oude Elberink JNG, Raat H, DunnGalvin A, et al. Health-related quality of life of food allergic patients: Comparison with the general population and other diseases. Allergy Eur J Allergy Clin Immunol. 2010;65(2):238-44. https://doi. org/10.1111/j.1398-9995.2009.02121.x 


\section{Supplementary}

\section{FAQOLQ-CF}

Cuestionario de calidad de vida- Alergia a alimentos - Formulario para niños (8-12 años)

- Las siguientes preguntas se refieren a tu alergia a alimentos, a cuánto afecta a tu calidad de vida.

- Es importante que rellenes la respuesta solo tú. Puedes pedir ayuda a tus padres, pero ellos no deben decirte qué respuesta elegir.

- Por favor, responde cada pregunta marcando la casilla adecuada con una " $x$ ". Las posibles respuestas son las de los dibujos.

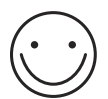

Nada

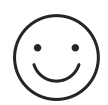

Casi nada

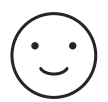

Un poco

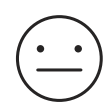

Regular

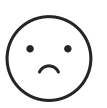

Bastante

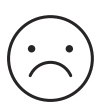

Mucho

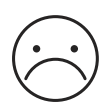

Muchísimo

Toda la información proporcionada es totalmente confidencial. El cuestionario será identificado por un código numérico.

A causa de tu alergia a alimentos, ¿cuánto te molesta ...

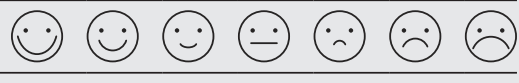

1 tener que vigilar siempre lo que comes?

2 poder comer menos cosas?

3 estar limitado en comprar cosas que te gustan?

4 tener que leer las etiquetas?

5 tener que rechazar comidas cuando estás con otros?

6 no poder quedarte a comer con alguien?

7 probar o comer menos cosas fuera de casa?

8 tener que avisar antes de lo que no puedes comer cuando comes fuera de casa?

9 tener que comprobar tú mismo si puedes comer algo cuando comes fuera de casa?

10 dudar de si comer algunos alimentos cuando no sabes si son seguros?

11 tener cuidado al tocar ciertos alimentos?

12 que no te den nada si alguien reparte golosinas en el cole?

$\begin{array}{lllllll}\square & \square & \square & \square & \square & \square & \square \\ \square & \square & \square & \square & \square & \square & \square \\ \square & \square & \square & \square & \square & \square & \square \\ \square & \square & \square & \square & \square & \square & \square \\ \square & \square & \square & \square & \square & \square & \square \\ \square & \square & \square & \square & \square & \square & \square \\ \square & \square & \square & \square & \square & \square & \square \\ \square & \square & \square & \square & \square & \square & \square \\ \square & \square & \square & \square & \square & \square & \square \\ \square & \square & \square & \square & \square & \square & \square \\ \square & \square & \square & \square & \square & \square & \square \\ \square & \square & \square & \square & \square & \square & \square\end{array}$

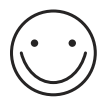

Nada

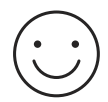

Casi nada

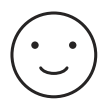

Un poco

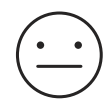

Regular

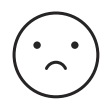

Bastante

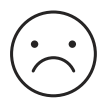

Mucho

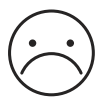

Muchísimo

\footnotetext{
A causa de tu alergia a alimentos, ¿cuánto te molesta ...

13 que cambien los ingredientes de un producto?

14 que la etiqueta diga: "Puede contener trazas de ..."?

15 tener que explicar a la gente que tienes alergia a algún alimento?

16 que la gente se olvide que tienes alergia a algún alimento?

17 que los demás puedan comer el alimento al que le tienes alergia cuando estás con otras personas?

18 no conocer el sabor de las cosas que no puedes comer?
}

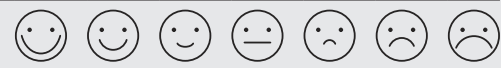

A causa de tu alergia a alimentos, ¿cuánto te asusta ...

$\begin{array}{lllllll}\square & \square & \square & \square & \square & \square & \square \\ \square & \square & \square & \square & \square & \square & \square \\ \square & \square & \square & \square & \square & \square & \square \\ \square & \square & \square & \square & \square & \square & \square \\ \square & \square & \square & \square & \square & \square & \square\end{array}$

19 tener una reacción alérgica?

20 comer el alimento prohibido por error?

21 comer algo que nunca has comido antes?

Por favor, responde las siguientes preguntas

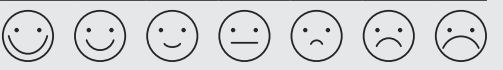

$\square \quad \square \quad \square \quad \square \quad \square \quad \square$ $\square \quad \square \quad \square \quad \square \quad \square \quad \square \quad \square$ $\square \quad \square \quad \square \quad \square \quad \square \quad \square \quad \square$

22 ¿Cuánto te preocupa que pueda ocurrir que nunca se te quite tu alergia a alimentos?

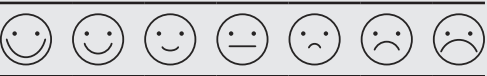

23 ¿Cuánto te entristeces cuando la gente no tiene en cuenta tu alergia a alimentos?

24 ¿Cuánto te entristece tener alergia a alimentos?

$\begin{array}{lllllll}\square & \square & \square & \square & \square & \square & \square \\ \square & \square & \square & \square & \square & \square & \square \\ \square & \square & \square & \square & \square & \square & \square\end{array}$


FAIM: Food Allergy Independent Measure- Child form (8-12 años)

Medida independiente de la alergia a alimentos - Versión niños (8-12 años)

Las siguientes cuatro preguntas se refieren a lo que piensas del riesgo de que te pase algo a causa de tu alergia a alimentos. Escoge una de las respuestas. Luego hay dos preguntas más sobre tu alergia. Responde, por favor, cada pregunta marcando con una " $x$ " en la respuesta adecuada

\begin{tabular}{|c|c|c|c|c|c|c|c|c|c|c|c|c|}
\hline & 0 & 1 & 2 & 3 & 4 & \multicolumn{2}{|l|}{5} & \multicolumn{5}{|c|}{6} \\
\hline & $\begin{array}{l}\text { Ninguno } \\
\text { (0\% de riesgo) }\end{array}$ & $\begin{array}{l}\text { Muy poco } \\
\text { riesgo }\end{array}$ & $\begin{array}{l}\text { Poco } \\
\text { riesgo }\end{array}$ & $\begin{array}{l}\text { Riesgo } \\
\text { intermedio }\end{array}$ & $\begin{array}{l}\text { Bastante } \\
\text { riesgo }\end{array}$ & \multicolumn{2}{|c|}{$\begin{array}{l}\text { Mucho } \\
\text { riesgo }\end{array}$} & \multicolumn{5}{|c|}{$\begin{array}{c}\text { Todo } \\
\text { (100\% de riesgo) }\end{array}$} \\
\hline & \multicolumn{5}{|c|}{ ¿En tu opinión, cuánto riesgo hay de que ... } & 0 & 1 & 2 & 3 & 4 & 5 & 6 \\
\hline a & \multicolumn{5}{|c|}{ por error comas algo a lo que tienes alergia? } & $\square$ & $\square$ & $\square$ & $\square$ & $\square$ & $\square$ & $\square$ \\
\hline b & \multicolumn{5}{|c|}{ tengas una reacción grave si, por error, comes algo a lo que tienes alergia? } & $\square$ & $\square$ & $\square$ & $\square$ & $\square$ & $\square$ & $\square$ \\
\hline C & \multicolumn{5}{|c|}{ puedas morir si, por error, comes algo a lo que tienes alergia? } & $\square$ & $\square$ & $\square$ & $\square$ & $\square$ & $\square$ & $\square$ \\
\hline d & \multicolumn{5}{|c|}{$\begin{array}{l}\text { no puedas tratar correctamente tu reacción alérgica si, por error, comes algo a lo que } \\
\text { tienes alergia? }\end{array}$} & $\square$ & $\square$ & $\square$ & $\square$ & $\square$ & $\square$ & $\square$ \\
\hline
\end{tabular}

e ¿Cuántos alimentos tienes que evitar a causa de tu alergia a alimentos?

$\square$

Casi

ninguno

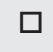

Muy

pocos

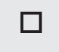

Pocos $\square$

Algunos $\square$

Muchos $\square$

Muchísimos $\square$

Casi todos

f Todo el mundo comparte actividades con otras personas, como jugar con amigos, ir a un cumpleaños, ir de visita, quedar con alguien para comer o salir a comer fuera. Tu alergia a alimentos ¿cuánto afecta a estas actividades?

$\square$

Tan poco que ni lo noto

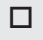

Muy

poco
Poco $\square$

Bastante $\square$

Mucho $\square$ Muchísimo 
Table E1 Modifications in Cronbach's alpha for each question in the domain of allergen avoidance (Cronbach's alpha $=0.863)$.

\begin{tabular}{lcc}
\hline & Cronbach's alpha when an item was deleted & Corrected item/total correlation \\
\hline 4 Read labels & 0.840 & 0.657 \\
6 Stay for a meal & 0.862 & 0.489 \\
7 Try fewer & 0.853 & 0.559 \\
8 Tell beforehand & 0.839 & 0.660 \\
9 Check yourself & 0.829 & 0.729 \\
10 Hesitate eating & 0.847 & 0.607 \\
15 Explain around & 0.830 & 0.723 \\
\hline
\end{tabular}

Table E2 Modifications in Cronbach's alpha for each question in the domain of risk of accidental exposure (Cronbach's alpha $=0.654$ ).

\begin{tabular}{lcc}
\hline & Cronbach's alpha when an item was deleted & Corrected item/total correlation \\
\hline 11 Touching foods & 0.594 & 0.423 \\
13 Ingredients change & 0.624 & 0.356 \\
14 Label traces & 0.645 & 0.310 \\
16 People forget & 0.572 & 0.471 \\
17 Others can eat & 0.565 & 0.479 \\
\hline
\end{tabular}

Table E3 Modifications in Cronbach's alpha for each question in the domain of emotional impact $($ Cronbach's alpha $=0.812)$.

\begin{tabular}{lcc}
\hline & Cronbach's alpha when an item was deleted & Corrected item/total correlation \\
\hline 19 Allergic reaction? & 0.777 & 0.613 \\
20 Eating wrong & 0.786 & 0.565 \\
21 Never before & 0.795 & 0.532 \\
22 Never get rid & 0.783 & 0.569 \\
23 Not taking into account & 0.787 & 0.557 \\
24 Have food allergy & 0.766 & 0.641 \\
\hline
\end{tabular}

Table E4 Modifications in Cronbach's alpha for each question in the domain of dietary restriction (Cronbach's alpha $=0.769)$.

\begin{tabular}{lcc}
\hline & Cronbach's alpha when an item was deleted & Corrected item/total correlation \\
\hline 1 Always watch & 0.745 & 0.469 \\
2 Eating fewer things & 0.708 & 0.631 \\
3 Limited in buying & 0.723 & 0.556 \\
5 Refuse food & 0.705 & 0.623 \\
12 Don't get treats & 0.771 & 0.379 \\
18 Don't know taste & 0.751 & 0.459 \\
\hline
\end{tabular}

